\title{
Production responses to rumen-protected choline and methionine supplemented during the periparturient period differ for primi- and multiparous cows
}

\author{
S. B. Potts, (1) C. M. Scholte, 장 K. M. Moyes, (1) and R. A. Erdman* (1) \\ Department of Animal and Avian Sciences, University of Maryland, College Park 20742
}

\begin{abstract}
The objective of this experiment was to examine production performance responses to feeding rumenprotected choline (RPC) or methionine (RPM), or both, during the periparturient period. Fifty-four Holstein cows (25 primiparous, 29 multiparous) were used in a randomized block design experiment with a $2 \times$ 2 factorial treatment structure. Cows were blocked by expected calving date and parity and assigned to 1 of 4 treatments: CON (no RPC or RPM); RPC $(13.0 \mathrm{~g} / \mathrm{d}$ of choline ion); RPM (9 g/d of DL-methionine prepartum; $13.5 \mathrm{~g} / \mathrm{d}$ of DL-methionine postpartum); or RPC + RPM. Treatments were applied once daily as a topdress from 3 wk before through 5 wk after calving. Dry matter intake and milk production were recorded daily, and milk samples were obtained once weekly. Data were analyzed for primi- and multiparous cows separately, using a repeated-measures mixed model that included random effects of cow and block and fixed effects of RPC, RPM, week, and their interactions; week served as the repeated effect. Initial BW and previous lactation milk yield were included as covariates in the statistical model for multiparous cows. Feeding RPC without RPM increased milk yield for multiparous cows by $8.7 \mathrm{~kg} / \mathrm{d}$, but this increase was not observed when RPC was fed with RPM. In multiparous cows, feeding RPM increased milk fat concentration and tended to increase milk fat yield. Because of this, RPM increased fat-corrected milk (FCM) by $2.8 \mathrm{~kg} / \mathrm{d}$ at wk 2 postpartum, and this increase was sustained through wk 5 postpartum. In contrast, RPM did not affect overall milk fat yield and concentration for primiparous cows. Feeding RPC increased milk yield for primiparous cows by $3.5 \mathrm{~kg} / \mathrm{d}$ irrespective of RPM inclusion, which is contrary to observations in multiparous cows, where RPC increased milk yield only in the absence of RPM.
\end{abstract}

Received September 16, 2019.

Accepted February 14, 2020.

*Corresponding author: erdman@umd.edu
These results indicate that responses to RPC during the periparturient period may be dependent upon supply of methionine. Our observations also demonstrate that primi- and multiparous cows respond differently to RPC and RPM supplemented individually or simultaneously during the periparturient period. This variation in response could have been mediated by putative differences in choline and methionine requirements of primiparous versus multiparous cows, or by differences in the levels of milk production between the 2 groups (36 vs. $25 \mathrm{~kg}$ of FCM/d). However, cows in this study did not experience severe negative energy balance (mean nadirs of -6.6 and $-5.0 \mathrm{Mcal} / \mathrm{d}$ for multiparous and primiparous cows, respectively), which likely affected their responses to RPC and RPM.

Key words: transition cow, choline, methionine

\section{INTRODUCTION}

Choline is an essential nutrient for most animals, including rats, preruminant calves (NRC, 2001), and humans (Zeisel and da Costa, 2009). Because choline is a precursor for phosphatidylcholine (PC), which is required for very low density lipoprotein synthesis $(\mathrm{Li}$ and Vance, 2008), choline deficiency impedes triglyceride (TG) export from the liver and can result in fatty liver disease (Zeisel, 1981). Choline requirements for lactating dairy cows have not been specified (NRC, 2001); however, increased prevalence of fatty liver disease during early lactation (Jorritsma et al., 2001) suggests that choline supply may be insufficient during this time. Feeding rumen-protected choline (RPC) to feed-restricted dry cows consistently reduces liver TG content (Cooke et al., 2007; Zenobi et al., 2018b). In contrast, supplementing periparturient cows with RPC has decreased (Zom et al., 2011) or had no effect on liver TG content (Zhou et al., 2016a; Zenobi et al., 2018a). In their meta-analysis, Arshad et al. (2020) also indicated that RPC supplementation during the periparturient period had no effect on liver TG content in multiparous cows. Production responses of periparturient cows fed 
RPC are also variable (Piepenbrink and Overton, 2003; Elek et al., 2008; Zom et al., 2011; Zhou et al., 2016a). The predicted production responses to supplementing $12.9 \mathrm{~g} / \mathrm{d}$ of RPC ion were 1.6 and $1.7 \mathrm{~kg} / \mathrm{d}$ for milk and ECM, respectively, in multiparous cows (Arshad et al., 2020). Furthermore, in their meta-analysis, Arshad et al. (2020) also indicated that choline increased milk fat and protein yields but not their concentrations.

Methionine and Lys are the 2 most limiting amino acids in dairy cattle diets (NRC, 2001). Methionine is not only required for protein synthesis, but also serves as the precursor for $S$-adenosylmethionine, the most predominant methyl donor in the body, which is required for the de novo synthesis of PC ( $\mathrm{Li}$ and Vance, 2008). Therefore, Met may indirectly improve liver TG export via very low density lipoprotein, through its participation in PC synthesis. Furthermore, Met can also be used as a precursor of glutathione, an important antioxidant (Meister and Anderson, 1983; Yuan and Kaplowitz, 2009). Supplementing rumen-protected Met (RPM) during the periparturient period generally increases milk protein concentration (Ordway et al., 2009; Osorio et al., 2013; Zhou et al., 2016a) and improves immune cell function by enhancing phagocytosis and oxidative burst activities (Zhou et al., 2016b). Supplementing RPM during the periparturient period has also been shown to increase milk yield (Zhou et al., 2016a) but to have no effect on liver TG content (Osorio et al., 2013; Zhou et al., 2016a; Batistel et al., 2017).

Variations in responses to RPM and RPC supplemented during the periparturient period are likely due to many factors, including the length of prepartum supplementation, the amount and availability of choline or Met supplied, and the methyl and choline status, level of production, and physiological state of the cow. A paucity of information exists comparing responses in primi- and multiparous cows (Arshad et al., 2020). Although choline and Met requirements likely differ between primi- and multiparous cows, periparturient choline and Met supplementation strategies are similar for both groups. However, because primiparous cows are still growing and produce less milk than mature cows, it is possible that they could respond to RPM or RPC differently than multiparous cows.

Because metabolism of both choline and Met are interrelated through methyl metabolism, supplementing both simultaneously may improve production performance during the periparturient period. Previous work by Zhou et al. (2016a) did not show a synergistic effect of feeding RPC and RPM simultaneously. However, results from a recent meta-analysis (Arshad et al., 2020) indicated that milk production responses to RPC were diminished as metabolizable Met, expressed as a percentage of MP, increased. These findings sug- gest that additional research is warranted to further the understanding of potential roles played by choline and Met during the periparturient period and how individual and simultaneous supplementation affect cow performance during this time. Therefore, the objective of this experiment was to examine the effects of feeding RPC and RPM, and potential interactions of RPC and $\mathrm{RPM}$, during the periparturient period on production of primi- and multiparous cows.

\section{MATERIALS AND METHODS}

All experimental procedures that used animals were approved by the University of Maryland, College Park Institutional Animal Care and Use Committee.

\section{Animals and Study Design}

Between March and December 2017, 25 primiparous and 29 multiparous Holstein cows from the Central Maryland Research and Education Center (Ellicott City, MD) were selected for use in a randomized block design experiment with a $2 \times 2$ factorial treatment structure. The 2 factors were 0 or $60 \mathrm{~g} / \mathrm{d}$ of RPC $(28.8 \%$ choline chloride; ReaShure, Balchem Corp., New Hampton, $\mathrm{NY})$ and 0 or $12 \mathrm{~g} / \mathrm{d}$ of RPM (75\% DL-methionine; Smartamine M, Adisseo USA, Inc., Alpharetta, GA) prepartum and $18 \mathrm{~g} / \mathrm{d}$ of RPM postpartum. Supplementation rates for RPC and RPM were selected based on manufacturer feeding recommendations. Thus, the 4 resulting treatments were as follows: (1) no supplemental choline or Met (control, CON); (2) $60 \mathrm{~g} / \mathrm{d}$ of RPC (13.0 g/d of choline ion); (3) $12 \mathrm{~g} / \mathrm{d}$ of RPM prepartum and $18 \mathrm{~g} / \mathrm{d}$ of RPM postpartum $(9 \mathrm{~g} / \mathrm{d}$ or $13.5 \mathrm{~g} / \mathrm{d}$ of DL-Met, respectively); and (4) a combination of RPC and RPM treatments (RPC + RPM; $60 \mathrm{~g} / \mathrm{d}$ of RPC plus $12 \mathrm{~g} / \mathrm{d}$ of RPM prepartum and $18 \mathrm{~g} / \mathrm{d}$ of RPM postpartum).

Before the start of the experiment, animals were blocked by age (primiparous vs. multiparous) and expected calving date and randomly assigned to treatments. Treatments were applied daily as a top-dress, from $21 \mathrm{~d}$ before expected calving through $35 \mathrm{~d}$ postpartum. Throughout the experiment, cows were housed in a free-stall barn equipped with electronic feeding gates (American Calan Inc., Northwood, NH) to allow for recording of individual cow feed intake. Cows were trained to use the electronic feeding gates approximately $31 \mathrm{~d}$ before expected calving. Once trained to a specific gate, cows retained their assigned feeding gate for the duration of the experiment. Free-stalls were equipped with rubber mattresses and bedded with sawdust. Due to facility limitations, pre- and postpartum animals were housed in the same group throughout the 
study, except during calving. When calving appeared imminent, animals were moved to individual box-stalls until after parturition. Stocking density of the group pen (based on the number of available free-stalls) never exceeded $80 \%$ throughout the study.

Pre- and postpartum cows were fed their respective TMR throughout the study. All cows received the same basal prepartum diet (Table 1) starting $21 \mathrm{~d}$ before expected calving. After calving, cows received the same basal lactation diet (Table 1) until $35 \mathrm{~d}$ postpartum. Treatments were applied daily as a top-dress immediately after feed delivery and hand-mixed into the top third of the feed offered. Cows were fed once daily at $0800 \mathrm{~h}$ for ad libitum intake ( $\sim 5$ to $10 \%$ orts). Feed refusals were removed each morning before the delivery of fresh feed. After calving, cows were milked twice daily in a milking parlor at 0600 and $1600 \mathrm{~h}$. All animals were visually observed twice daily for signs of illness. Upon signs of illness, cows were treated as directed by the herd veterinarian.

\section{Data Collection and Sample Analysis}

Feed Intake and Diet Composition. Individual feed intake was recorded daily, as feed offered minus feed refused. Samples of individual feed ingredients were collected once weekly throughout the study and composited before analysis of nutrient composition by wet chemistry methods (Cumberland Valley Analytical Services, Waynesboro, PA). Additional samples of silage were analyzed monthly via near-infrared reflectance spectroscopy (Cumberland Valley Analytical Services) so that diet adjustments could be made to maintain consistency throughout the study. Dry matter of haylage and corn silage was determined twice weekly to maintain a constant mixture of feed ingredients on a DM basis.

Body Weight, Body Condition, Rumination, and Calving Data. Postpartum BW was recorded electronically twice daily upon exit from the milking parlor; prepartum BW was recorded 3 times per week using the same scale system. Body condition scores (5-point scale; $1=$ thin, $5=$ fat; Wildman et al., 1982) were determined independently by 2 trained investigators each week. Daily rumination time (minutes per day) was collected electronically using the SCR Dairy system (Allflex USA Inc., Irving, TX). Calving difficulty scores were assigned on a 1 -to- 5 scale $(1=$ no assistance, 5 = extreme difficulty; Djemali et al., 1987), and calf sex and BW were recorded at calving.

Milk. After calving, milk yield was recorded electronically at each milking. At approximately d 7, 14, 21,28 , and 35 postpartum, samples of milk were collected from 2 consecutive milkings for analysis of fat,
Table 1. Ingredient and nutrient composition (\% of DM) of the basal pre- and postpartum diets $^{1}$

\begin{tabular}{|c|c|c|}
\hline Item & Prepartum & Postpartum \\
\hline \multicolumn{3}{|l|}{ Ingredient } \\
\hline Corn silage & 44.0 & 29.2 \\
\hline Legume silage & - & 11.6 \\
\hline Timothy hay & 30.0 & - \\
\hline Alfalfa hay & - & 7.9 \\
\hline Ground corn & 2.0 & 19.5 \\
\hline Soybean hulls & 5.3 & 9.0 \\
\hline Dried molasses & - & 2.8 \\
\hline SoyPlus $^{2}$ & 2.7 & 6.6 \\
\hline Soybean meal & 6.8 & 6.5 \\
\hline ProvAAl $^{2}$ MetAAtein ${ }^{2}$ & 1.1 & 1.7 \\
\hline Megalac $^{2}$ & - & 1.4 \\
\hline Fresh mineral mix $^{3}$ & - & 3.8 \\
\hline Close-up mineral mix ${ }^{4}$ & 8.1 & - \\
\hline \multicolumn{3}{|l|}{ Nutrient } \\
\hline DM, $\%$ as fed & 48.4 & 51.9 \\
\hline $\mathrm{NDF}$ & 45.7 & 32.9 \\
\hline $\mathrm{ADF}$ & 27.7 & 21.4 \\
\hline Lignin & 3.9 & 3.3 \\
\hline $\mathrm{CP}$ & 14.3 & 16.7 \\
\hline $\mathrm{MP}^{4}$ & 9.32 & 10.40 \\
\hline Lys, ${ }^{5} \%$ of MP & 6.71 & 6.74 \\
\hline Met, ${ }^{5} \%$ of MP & 1.77 & 1.82 \\
\hline Lys:Met & 3.79 & 3.70 \\
\hline Starch & 16.0 & 24.0 \\
\hline TDN & 66.7 & 67.0 \\
\hline Crude fat & 2.4 & 2.6 \\
\hline $\mathrm{NE}_{\mathrm{L}}, \mathrm{Mcal} / \mathrm{kg}$ & 1.51 & 1.62 \\
\hline Ash & 6.7 & 7.6 \\
\hline Calcium & 1.1 & 1.1 \\
\hline Phosphorus & 0.38 & 0.40 \\
\hline Magnesium & 0.44 & 0.30 \\
\hline Potassium & 1.5 & 1.9 \\
\hline Sulfur & 0.42 & 0.30 \\
\hline Sodium & 0.08 & 0.50 \\
\hline Chloride & 0.95 & 0.60 \\
\hline $\mathrm{DCAD},{ }^{6} \mathrm{mEq} / \mathrm{kg}$ & -103 & 369 \\
\hline
\end{tabular}

${ }^{1}$ Nutrient composition was calculated from wet chemistry analysis of individual feed ingredients sampled weekly throughout the study. Cows on all treatments received the same base diet throughout the study, with treatments applied daily as a top-dress.

${ }^{2}$ Soyplus: Landus Cooperative, Ames, IA. Megalac: Church \& Dwight Co. Inc., Ewing, NJ. ProvAAl2 MetAAtein (Perdue AgriBusiness, Salisbury, MD) contains Lys (4.5\% digestible RUP) and Met $(0.6 \%$ digestible RUP).

${ }^{3}$ Fresh mineral mix included $20.4 \%$ limestone, $18.5 \%$ sodium bicarbonate, $12.3 \%$ salt, $7.7 \%$ OmniGen-AF (Phibro Animal Health Corporation, Teaneck, NJ), $7.7 \%$ Diamond V XP (Diamond V, Cedar Rapids, IA), $6.2 \%$ potassium carbonate, $6.2 \%$ cane molasses, $5.6 \%$ Dynamate (The Mosaic Company, Plymouth, MN), $3.9 \%$ urea, $3.2 \%$ magnesium oxide, $2.5 \%$ Bio-fos (The Mosaic Company), $1.9 \%$ Rumensin (Elanco, Greenfield, IN), $0.93 \%$ vitamin A, D, and E mix, $0.87 \%$ selenium, $0.87 \%$ Sel-Plex 600 (Alltech, Lexington, KY), $0.87 \%$ trace mineral salt, and $0.50 \%$ vitamin $\mathrm{E}(125,000 \mathrm{U})$.

${ }^{4}$ Close-up mineral mix included $44.4 \%$ Animate (Phibro Animal Health Corporation), 27.2\% limestone, 5.6\% Diamond V XP (Diamond V), $5.9 \%$ OmniGen-AF (Phibro Animal Health Corporation), 3.6\% cane molasses, 3.4\% Bio-fos (The Mosaic Company), 2.9 urea, 1.5\% salt, $1.4 \%$ Rumensin (Elanco), $1.5 \%$ magnesium oxide, $0.65 \%$ vitamin $\mathrm{A}, \mathrm{D}$, and E mix, 0.55\% vitamin E (125,000 U), 0.50\% Sel-Plex 600 (Alltech, Lexington, $\mathrm{KY}$ ), $0.50 \%$ selenium, and $0.50 \%$ trace mineral salt.

${ }^{5} \mathrm{MP}$, Lys as a $\%$ of MP, and Met as a $\%$ of MP were predicted from NRC (2001) using the average prepartum or postpartum DMI for all cows.

${ }^{6} \mathrm{DCAD}=\left[\left(\mathrm{Na}^{+}+\mathrm{K}^{+}\right)-\left(\mathrm{Cl}^{-}+\mathrm{S}^{-2}\right)\right] ; \mathrm{NRC}(2001)$. 
true protein, and SCC by Lancaster DHIA (Lancaster, PA).

Blood. Blood was collected via coccygeal venipuncture in the morning before feeding on approximately $-21,-14,-7,0,4,7,11,14,21,28$, and 35 d relative to calving. Because some cows calved early or late, prepartum samples were actually collected $( \pm 2 \mathrm{~d})$ on $-19,-12$, and $-6 \mathrm{~d}$ relative to calving. Samples were collected into two 10-mL evacuated tubes containing potassium EDTA, one 6-mL evacuated tube containing sodium fluoride as a glycolytic inhibitor, and one 10$\mathrm{mL}$ evacuated tube containing sodium heparin. Tubes were immediately placed on ice and then centrifuged at $2,000 \times g$ for $15 \mathrm{~min}$ at $4^{\circ} \mathrm{C}$. Plasma aliquots were stored at $-20^{\circ} \mathrm{C}$ until analysis. Concentrations of fatty acids (FA) were determined using a colorimetric assay [HR Series NEFA-HR(2), Fujifilm Wako Diagnostics USA, Mountain View, CA]. Glucose and BHB concentrations were also determined using commercial colorimetric assays (Autokit Glucose, Fujifilm Wako Diagnostics USA; $\beta$-Hydroxybutyrate LiquiColor, \#2440, Stanbio Laboratory, Boerne, TX).

Liver. Approximately $120 \mathrm{mg}$ of liver tissue was collected from each animal via percutaneous liver biopsies on approximately d -21 (actual prepartum samples were obtained on $-19 \pm 2 \mathrm{~d}$ ) and $\mathrm{d} 7$ relative to parturition. The biopsy incision site was identified as the location where an imaginary line from the tuber coxae to the olecranon intersected the 11th intercostal space. Cows were restrained in a chute, and local anesthesia ( $2 \%$ lidocaine) was provided before a small incision was made in the skin and the biopsy needle inserted $(14 \mathrm{G} \times$ $15 \mathrm{~cm}$; Tru-Cut, Merit Medical, Jordan, UT). Approximately 10 passes of the biopsy needle were required to obtain $120 \mathrm{mg}$ of tissue. Tissue was immediately snap frozen in liquid nitrogen and stored at $-80^{\circ} \mathrm{C}$ until TG analysis. Liver lipids and TG were determined similarly to procedures outlined by Zenobi et al. (2018a), with slight modifications to accommodate analysis of $50 \mathrm{mg}$ of tissue instead of $100 \mathrm{mg}$. Approximately $50 \mathrm{mg}$ of liver tissue was homogenized in $1 \mathrm{~mL}$ of saline, followed by addition of $0.5 \mathrm{~mL}$ of a mixture of saline and methanol (1:1). Total lipids were extracted according to Folch et al. (1957), using $1 \mathrm{~mL}$ of homogenate; the remaining $0.5 \mathrm{~mL}$ of homogenate was used to determine $\mathrm{DM}$ content by drying at $60^{\circ} \mathrm{C}$ for $24 \mathrm{~h}$. Lipid extracts were analyzed for TG content using a colorimetric procedure (Foster and Dunn, 1973).

\section{Statistical Analysis}

Four cows were removed from the study early, for various reasons: 1 multiparous cow from the RPC + RPM treatment was removed during wk 3 postpartum due to a severe coliform mastitis infection; another multiparous cow that calved with twins on the RPC + RPM treatment was removed due to a retained placenta and severely depressed DMI that eventually led to a right-displaced abomasum during wk 2 postpartum; and 2 cows $(1$ multiparous on the CON treatment, 1 primiparous on the RPC $+\mathrm{RPM}$ treatment) were removed due to injuries. Data for these cows were used in the statistical analyses up to the day before they were removed from the study. Data from other cows that required health-related interventions for various reasons throughout the study (Table 2) were not excluded from the analysis. Instead, potential outliers were detected using Cook's distance for each variable, using a cutoff of $4 / n$. If a particular week for a cow was identified as a potential outlier for more than 4 response variables, data from that week were excluded from the statistical analysis for all variables. Based on this criteria, 8 individual weekly data points from 8 individual cows $(\mathrm{n}=$ 3 for primiparous; $\mathrm{n}=5$ for multiparous) were omitted before analysis.

Initial statistical analysis of data from both primiand multiparous cows revealed that primi- and multiparous cows seemed to respond differently to RPC and RPM. Unfortunately, the experimental design precluded proper investigation of parity $\times$ treatment interactions because parity was confounded with block. Therefore, all data were analyzed for primi- and multiparous cows separately. Production data were reduced to weekly means and analyzed using a repeatedmeasures mixed model using SAS (version 9.4; SAS Institute Inc., Cary, NC). Pre- and postpartum data were analyzed separately using a statistical model that included the random effect of cow nested within block and fixed effects of week relative to calving $(-3,-2$, $-1,1,2,3,4$, or 5$)$, the main effects of RPC and RPM, and all 2- and 3-way interactions. The Kenward-Roger method was used to adjust degrees of freedom. Week relative to calving served as the repeated factor. A total of 8 covariance structures were tested, and the one that yielded the lowest Akaike information criterion was selected for each variable. Because cows were only blocked by expected calving date and parity, data were also examined for potential differences in initial BW, initial BCS, the previous lactation's 305-d matureequivalent milk yield (305ME; multiparous cows), and lactation number (multiparous cows) among treatments. Results from this analysis (Table 3) indicated that initial BW and previous-lactation $305 \mathrm{ME}$ were different among the 4 treatment groups for multiparous cows. Therefore, initial BW and previous $305 \mathrm{ME}$ were included as covariates in the statistical model for multiparous cows. No covariates were included for primiparous cows. 
Table 2. Number of days on treatment prepartum, calving details, and health event counts for primiparous and multiparous cows fed the control $\operatorname{diet}(\mathrm{CON})$ or the control diet plus rumen-protected choline (RPC), rumen-protected methionine (RPM), or both $(\mathrm{RPC}+\mathrm{RPM})^{1}$

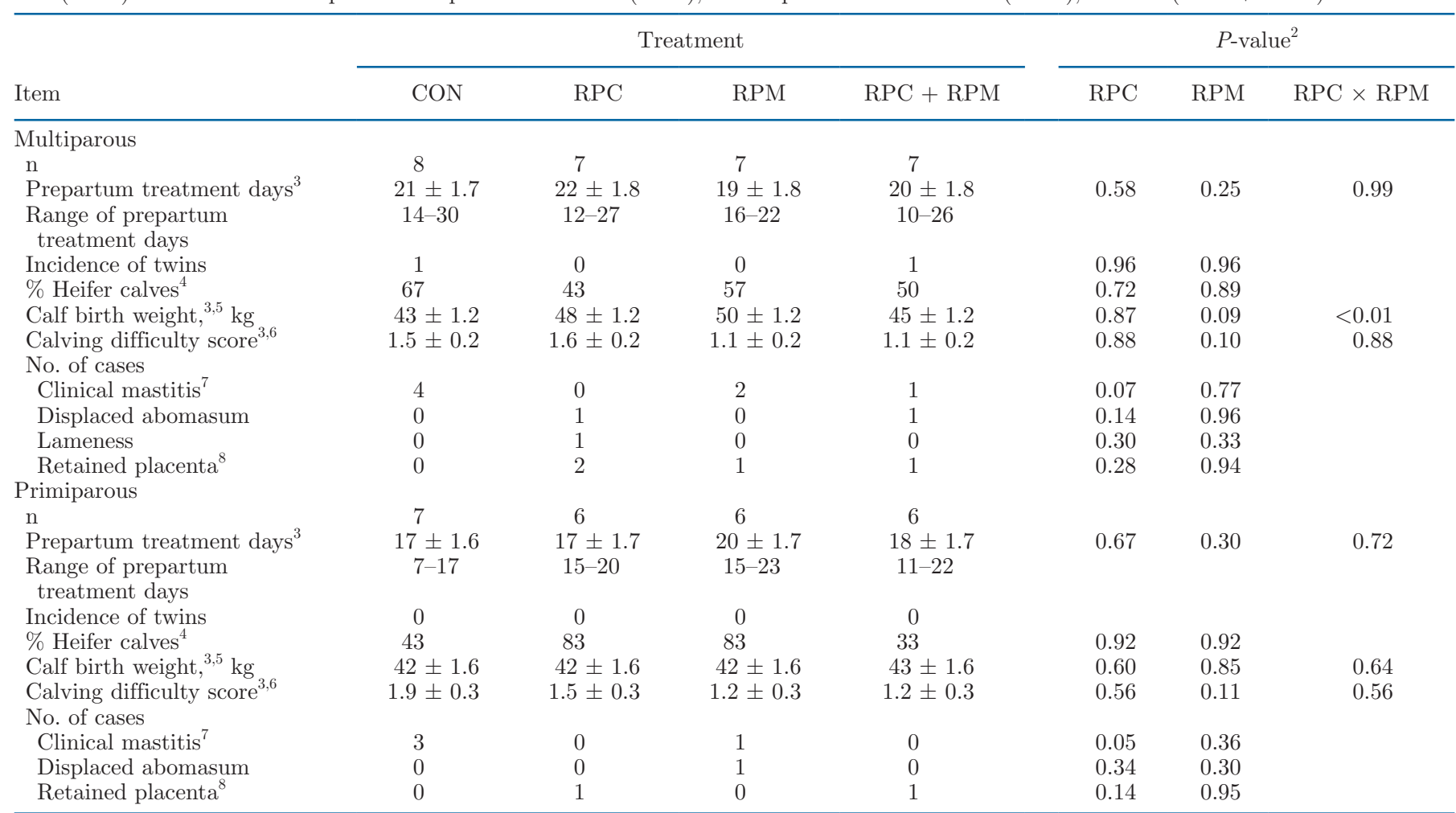

${ }^{1}$ Prepartum, cows were supplemented with 60 g/d RPC (ReaShure, Balchem Corp., New Hampton, NY), 12 g/d RPM (Smartamine M, Adisseo USA Inc., Alpharetta, GA), or both. Postpartum, cows were supplemented with $60 \mathrm{~g} / \mathrm{d}$ RPC, $18 \mathrm{~g} / \mathrm{d}$ RPM, or both. Cows were monitored, and treatments were applied from $21 \mathrm{~d}$ before expected calving through 35 DIM.

${ }^{2} P$-values for count data were generated using chi-squared analysis. Continuous data (prepartum treatment days, calf birth weight, and calving difficulty scores) were analyzed by 2-way ANOVA.

${ }^{3}$ Results are reported as LSM \pm SEM.

${ }^{4}$ Percentage of female calves born from cows on each treatment; calculations included 1 set of female twins born on the CON treatment and 1 set of male twins born on the RPC + RPM treatment for multiparous cows.

${ }^{5}$ Determined using a calf weigh tape (The Coburn Company Inc., Whitewater, WI) within $24 \mathrm{~h}$ of birth.

${ }^{6}$ Calving difficulty score: $1=$ no problem or unobserved; 2 = slight problem but no assistance; $3=$ needed assistance; $4=$ considerable force required; 5 extreme difficulty.

${ }^{7} \mathrm{~A}$ case of mastitis was considered clinical when a cow was treated with antibiotics based on signs of the milk and udder appearance.

${ }^{8}$ Defined as failure to expel fetal membranes within $24 \mathrm{~h}$ of calving.

Table 3. Average lactation number, previous lactation's 305-d mature equivalent milk yield (305ME), and initial BW and BCS for primi- and multiparous cows 1

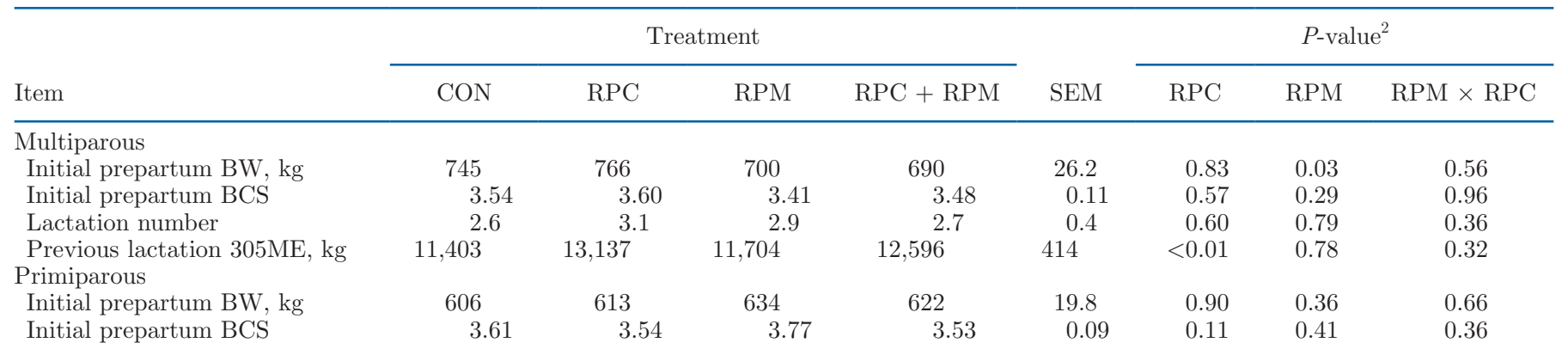

${ }^{1} \mathrm{CON}=$ control diet; $\mathrm{RPC}=$ control diet plus rumen-protected choline $\mathrm{RPM}=$ control diet plus rumen-protected methionine; $\mathrm{RPC}+\mathrm{RPM}$ = control diet with both RPC and RPM.

${ }^{2}$ Data were analyzed as 2-way ANOVA with fixed effects of RPC, RPM, and their interaction. 
Plasma FA, BHB, and glucose measurements were analyzed using a model similar to that used for production variables, except that the repeated factor (week) included additional levels to reflect the twiceweekly sampling times during the first 2 weeks after calving. Selection of appropriate covariance structures was performed as previously described for production variables, where the structure that yielded the lowest Akaike information criterion value was chosen for each variable. Covariance structures tested included unstructured, compound symmetry, heterogeneous compound symmetry, first-order antedependence, spatial power, spatial linear, spatial exponential, and spatial Gaussian. Postpartum liver TG data (d 7 postpartum) were analyzed using a mixed model (SAS version 9.4) that included the fixed main effects of RPC and RPM and their interaction. Prepartum liver TG content, determined from samples collected in the morning before application of first treatment $(\sim d-21)$, was also included in the model as a random covariate effect.

All data are presented as least squares means, unless otherwise noted. Residuals for each variable were visually assessed as an indicator of normal distribution. Residuals for plasma BHB and milk SCC appeared to violate this assumption, and both variables were log-transformed before statistical analysis. For ease of interpretation, back-transformed least squares means are reported. Significance was declared at $P \leq 0.05$, and tendencies were declared at $P \leq 0.10$. The SLICE option of the LSMEANS statement of SAS was used to help interpret significant interactions.

\section{RESULTS AND DISCUSSION}

\section{Diet}

Details regarding the pre- and postpartum basal diets are shown in Table 1. The NRC (2001) recommended a Lys:Met ratio of 3:1. In the current study, the basal Lys and Met contents were 6.71 and $6.74 \%$ and 1.77 and $1.82 \%$ of MP, respectively, for the base prepartum and postpartum diets, similar to those reported by others (Osorio et al., 2013; Zhou et al., 2016a). This resulted in Lys:Met ratios of 3.79:1 and 3.70:1, respectively. Thus, Met should have been limiting and Lys, in relation to Met, should not have been limiting in the base diet. However, the NRC (2001) recommendations for Lys and Met were based on studies that used mid-lactation, multiparous cows, not early-lactation cows. Given the positive production responses that are generally observed when RPM is supplemented to periparturient cows (Ordway et al., 2009; Osorio et al., 2013; Zhou et al., 2016a), the Met recommendations by the NRC (2001) may not be appropriate for early-lactation cows.

\section{Days on Treatment, Calving Details, and Health}

Details regarding the number of days on treatment prepartum, calving, and incidence of health disorders are shown in Table 2. On average, multiparous and primiparous cows received their respective treatments for approximately 20 and $18 \mathrm{~d}$ before calving, respectively (Table 2). We found no significant main effects of RPC or RPM on calving difficulty or calf birth weight. An $\mathrm{RPC} \times \mathrm{RPM}$ interaction for multiparous cows $(P<$ 0.01 ; Table 2) indicated a positive effect of RPM on calf birth weight in the absence of RPC and a positive effect of RPC on calf birth weight in the absence of RPM. Chi-squared analysis of health data indicated that cows fed RPC tended to have fewer cases of mastitis (Table 2 ); however, this result was driven by the numerically greater number of cases of mastitis in $\mathrm{CON}$ cows than in any other treatment group.

\section{Prepartum Performance}

Multiparous Cows. Prepartum DMI, BW, BCS, and energy balance of multiparous cows were unaffected by treatment (Table 4). Furthermore, plasma FA and glucose were unaffected by treatment (Table $5)$. However, an RPM $\times \mathrm{RPC} \times$ week interaction $(P$ $=0.02$ ) indicated that in the presence of RPM, RPC increased plasma BHB at $2 \mathrm{wk}$ before calving (Figure $1 \mathrm{~A}$ ), suggesting that multiparous cows had greater FA oxidation during this time. This apparent synergistic response is contrary to results reported by Zhou et al. (2016a), who did not observe changes in prepartum $\mathrm{BHB}$ in response to feeding RPC and RPM. However, the increase in $\mathrm{BHB}$ we observed at wk 2 prepartum for cows fed RPC with RPM was not maintained, and concentrations were unaffected by treatment throughout the remainder of the study.

In recent years, activity monitors have become popular for monitoring health and reproductive events in the dairy industry (Barkema et al., 2015). To our knowledge, this is the first study to report rumination activity in association with periparturient supplementation of RPC and RPM. We found no effect of RPC on rumination activity prepartum. However, RPM tended to reduce total daily rumination $(P=0.09)$, but not rumination per unit of DMI, during the prepartum period for multiparous cows (Table 4). This result is probably related to the numerically lower DMI for these cows during the prepartum period.

Primiparous Cows. Similar to multiparous cows, DMI, BW, and energy balance of primiparous cows were unaffected by treatment during the prepartum period (Table 4). However, in contrast to multiparous cows, we discovered effects of RPC on BCS and plasma 


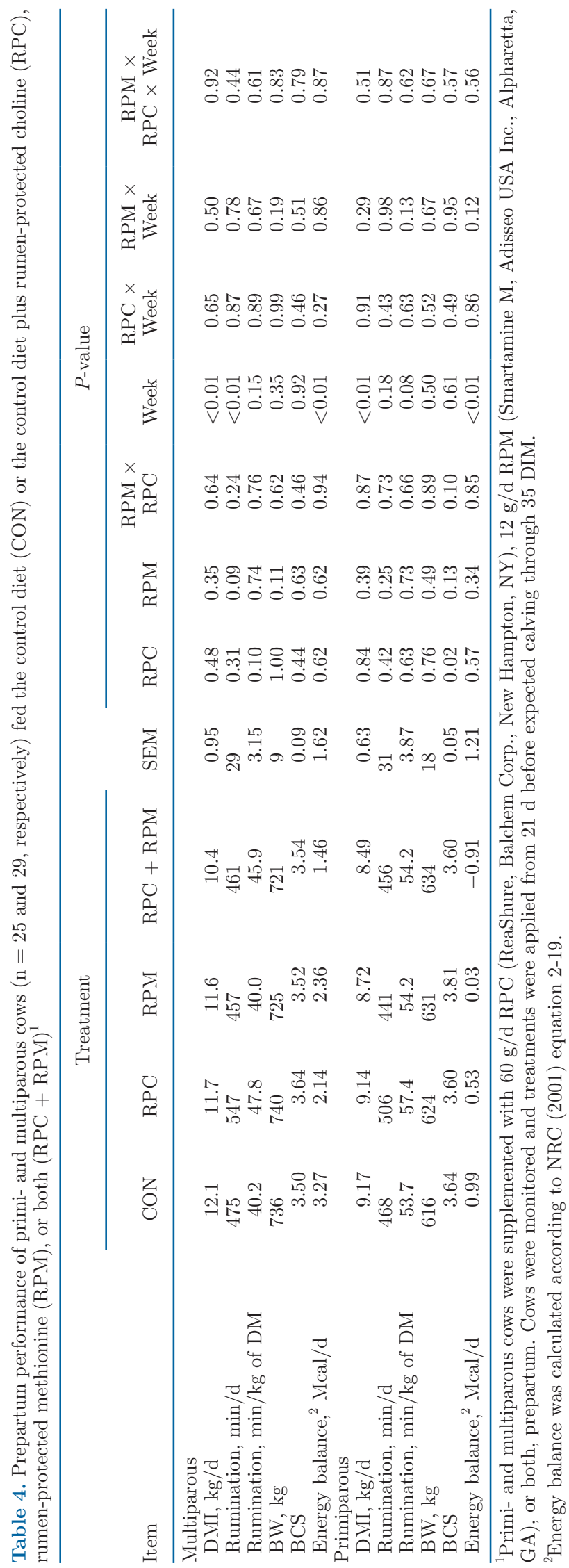

metabolites for primiparous cows. Although cows fed RPC had lower prepartum BCS $(P=0.02)$, this effect was likely driven by a tendency for an RPC $\times \mathrm{RPM}$ interaction $(P=0.10)$, where RPM supplemented in absence of RPC tended to increase BCS. Interestingly, although we found no effects of RPM on prepartum blood metabolites, RPC increased plasma FA $(P=$ $0.05)$ and tended to increase BHB $(P=0.09$; Table 5). This observation would coincide with an RPC-induced decrease in prepartum BCS. However, it is also possible that the numerically lower initial prepartum BCS for primiparous cows fed $\operatorname{RPC}(P=0.11$; Table 3$)$ influenced this observation.

Prepartum rumination activity was unaffected by treatment for primiparous cows. Interestingly, primiparous cows and multiparous cows spent similar amounts of time ruminating per day, despite multiparous cows having greater DMI. Our observations of total rumination time during the prepartum period are concordant with those of Kaufman et al. (2016), who reported that total daily rumination time was similar between primi- and multiparous cows until the second week of lactation.

\section{Postpartum Performance: DMI, BW, BCS, and Energy Balance}

Multiparous Cows. Postpartum energy balance, DMI, BCS, daily rumination, and BW were not affected by treatment in multiparous cows (Table 6). Contrary to our findings, Zhou et al. (2016a) showed that RPM increased postpartum DMI irrespective of RPC supplementation. However, because treatment had no effect on DMI, effects on production responses were not confounded with effects on intake in our study.

Primiparous Cows. Postpartum energy balance, DMI, daily rumination, and BCS of primiparous cows were not affected by treatment (Table 7). However, cows fed RPM had greater numerical BW during the first week postpartum $(\mathrm{RPM} \times$ week interaction, $P=$ 0.05 ; Figure 2B).

\section{Postpartum Performance: Milk Yield}

Multiparous Cows. An RPC $\times$ RPM interaction for milk yield $(P=0.02$; Table 6$)$ indicated that RPC increased milk yield in absence of RPM supplementation. Milk yield was unaffected by RPC when RPM was fed. Although Zhou et al. (2016a) previously reported no effect of RPC on milk yield regardless of RPM supplementation in periparturient cows, our observation corresponds with the negative interaction with metabolizable Met and production responses to RPC described in the meta-analysis by Arshad et al. (2020). 
Potts et al.: CHOLINE OR METHIONINE IN THE PERIPARTURIENT PERIOD

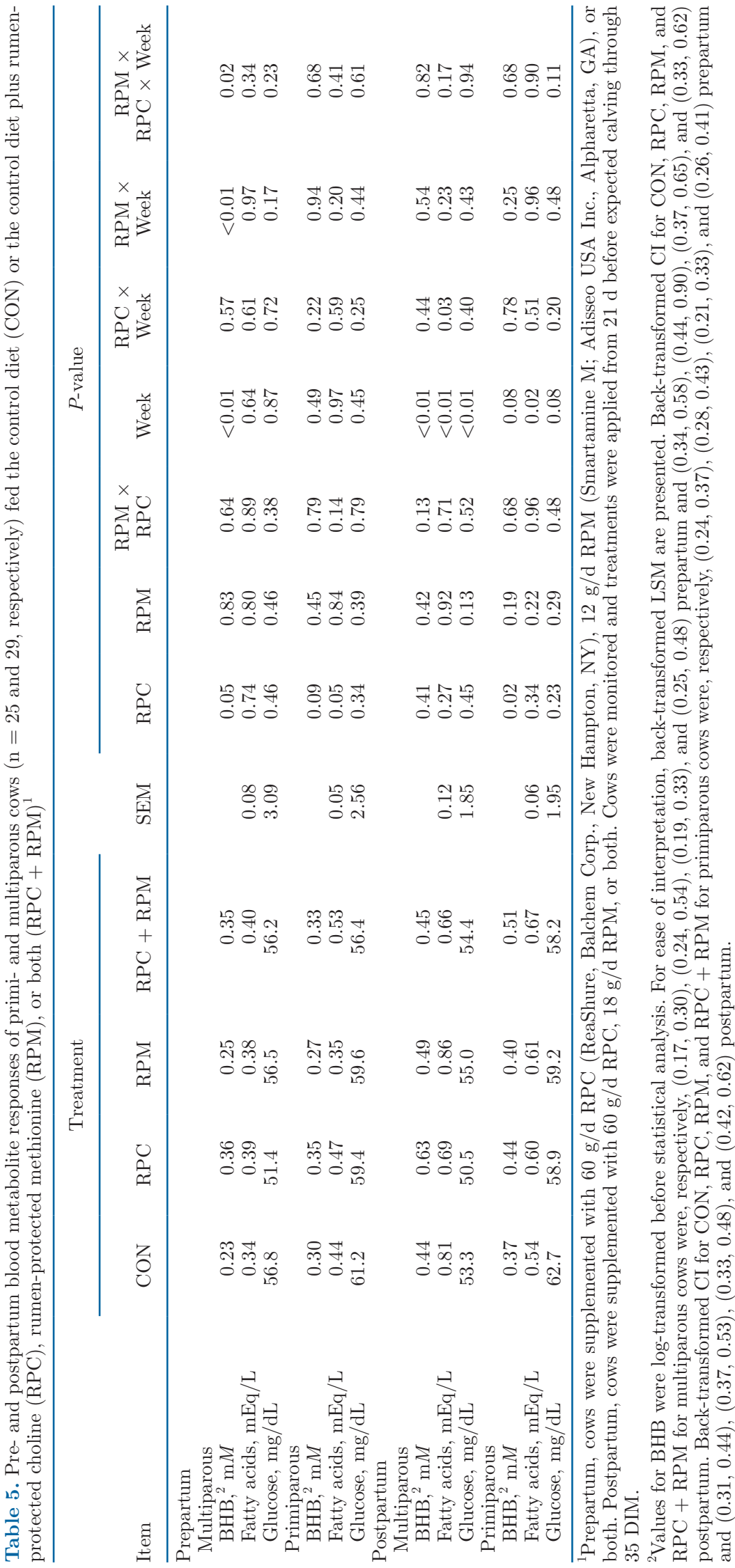


A

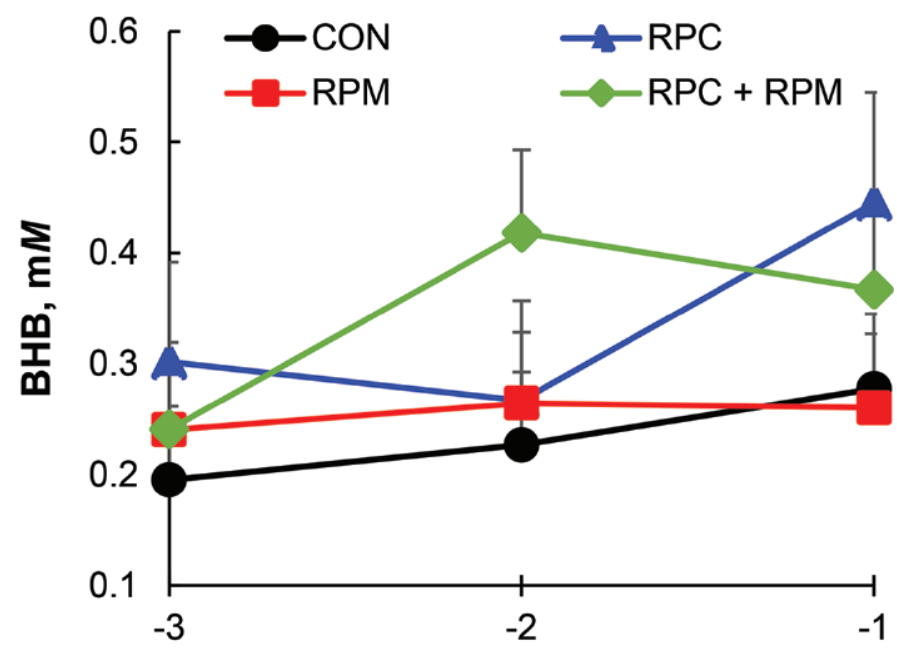

B

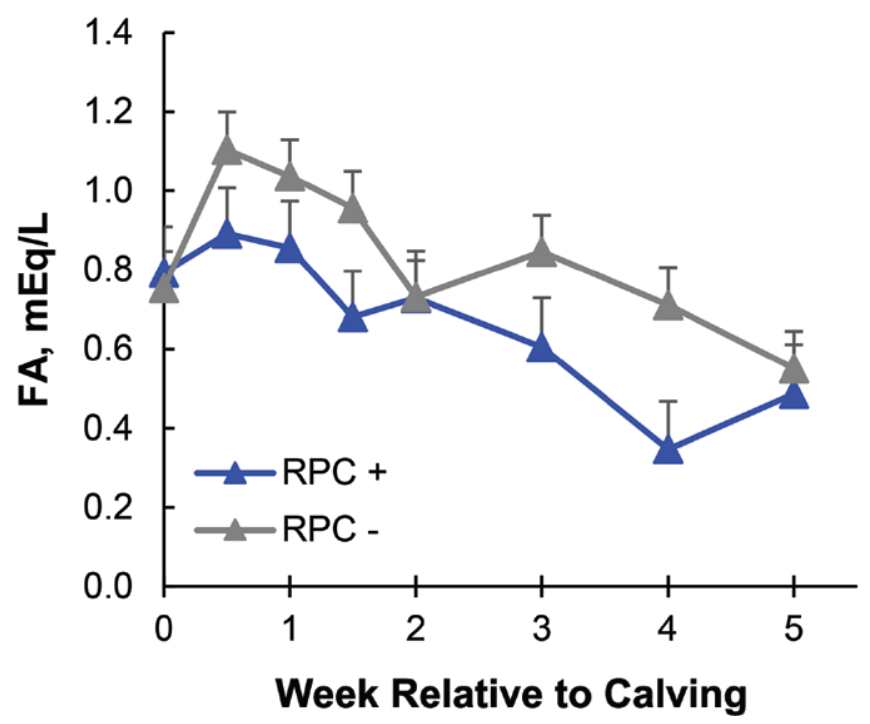

Figure 1. Prepartum plasma BHB (A) and postpartum plasma fatty acid (FA; B) concentrations for multiparous cows fed control diet $(\mathrm{CON}), \mathrm{CON}$ plus $60 \mathrm{~g} / \mathrm{d}$ rumen-protected choline $(\mathrm{RPC})$ or $\mathrm{CON}$ plus $12 \mathrm{~g} / \mathrm{d}$ rumen-protected methionine (RPM) prepartum and 18 $\mathrm{g} / \mathrm{d}$ RPM postpartum, or both (RPC + RPM). Values for BHB were log-transformed before statistical analysis. For ease of interpretation, back-transformed LSM are presented. For prepartum BHB, we found an $\mathrm{RPM} \times \mathrm{RPC} \times$ week interaction $(P=0.02)$. For postpartum FA, the $\mathrm{RPC} \times$ week interaction was significant $(P=0.03)$.

In their meta-analysis, Arshad et al. (2020) reported a $1.6 \mathrm{~kg} / \mathrm{d}$ response in milk production in multiparous cows fed $12.9 \mathrm{~g} / \mathrm{d}$ of RPC, expressed as choline ion equivalents. However, the response to RPC was greatly diminished as metabolizable Met increased in the diet. These findings, along with the results of the current study, suggest that a greater supply of metabolizable Met suppresses the positive RPC milk response in pe- riparturient cows. Because previous studies have shown RPC to increase (Elek et al., 2008; Zenobi et al., 2018a) or have no effect (Zom et al., 2011; Leiva et al., 2015; Zhou et al., 2016a) on milk yield of periparturient multiparous cows, this hypothesis might explain some of the variation in response to RPC.

Primiparous Cows. In contrast to multiparous cows, RPC increased overall milk yield by $3.1 \mathrm{~kg} / \mathrm{d}$ for primiparous cows irrespective of RPM supplementation $(P=0.04$; Table 7$)$. This observation is contrary to results reported by Zhou et al. (2016a), who showed no effect of RPC, fed with or without RPM, on milk yield in periparturient multiparous cows. However, our results are in agreement with those reported by Zenobi et al. (2018a), who showed a tendency for RPC to increase milk yield of multiparous cows by approximately $2 \mathrm{~kg} / \mathrm{d}$ during the early lactation period. In the current study, we discovered minor effects of RPM on milk yield. An $\mathrm{RPM} \times$ week interaction $(P=0.02$; Figure $2 \mathrm{~A})$ indicated that cows fed RPM had numerically greater milk yield during wk 1 postpartum. However, after wk 2 postpartum, cows fed RPM had numerically lower milk yield for the remainder of the study (Figure 2A).

\section{Postpartum Performance: Milk Fat Production}

Multiparous Cows. Feeding RPM increased overall milk fat percentage $(P=0.01)$ and tended to increase overall milk fat yield $(P=0.09)$, but we found no effects of RPC on milk fat production (Table 6). The tendency for RPM to enhance milk fat yield was likely driven by the RPM-induced increase in milk fat percentage. This increase in milk fat yield translated to significantly greater $4 \% \mathrm{FCM}$ production at wk 2 postpartum for cows fed RPM $(\mathrm{RPM} \times$ week interaction; $P<0.01)$, a difference that was maintained numerically throughout the remainder of the study (Figure 3A). These findings contrast with those of others (Zhou et al., 2016a; Batistel et al., 2017), who showed that RPM increased milk fat yield independent of milk fat concentration. However, those studies also reported RPM-related increases in milk yield and DMI, effects that we did not observe in the current study. Recent research with bovine mammary epithelial cells indicated that Met enhances milk fat synthesis via activation of transcription factors that ultimately increase protein expression of sterol regulatory element binding protein 1-c (SREBP-1c; Qi et al., 2018; Li et a., 2019). Because SREBP-1c is known to control milk fat synthesis in cattle (Bauman et al., 2011), this finding provides an additional mechanism by which RPM could enhance milk fat concentration.

It is generally recommended to minimize the extent of negative energy balance during the early postpartum period, to improve the success with which a cow adapts 
Potts et al.: CHOLINE OR METHIONINE IN THE PERIPARTURIENT PERIOD

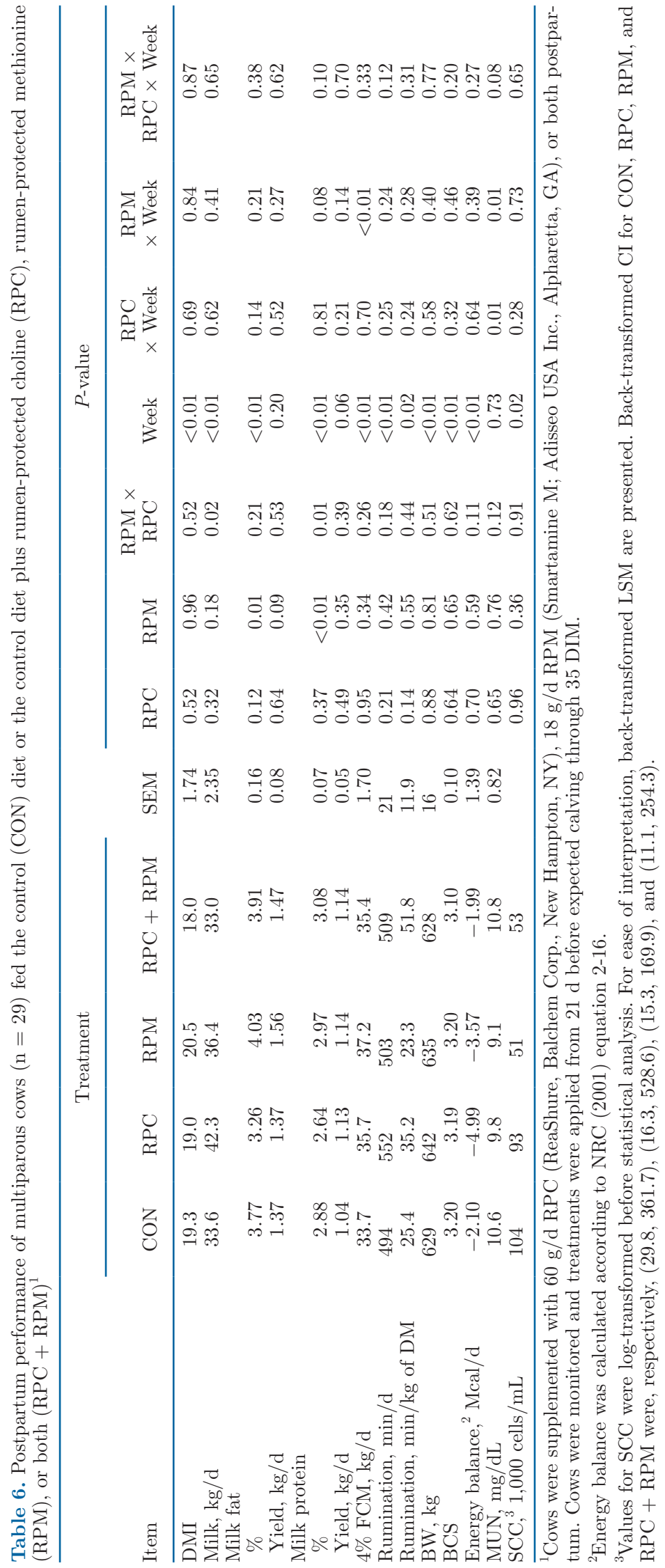


Potts et al.: CHOLINE OR METHIONINE IN THE PERIPARTURIENT PERIOD

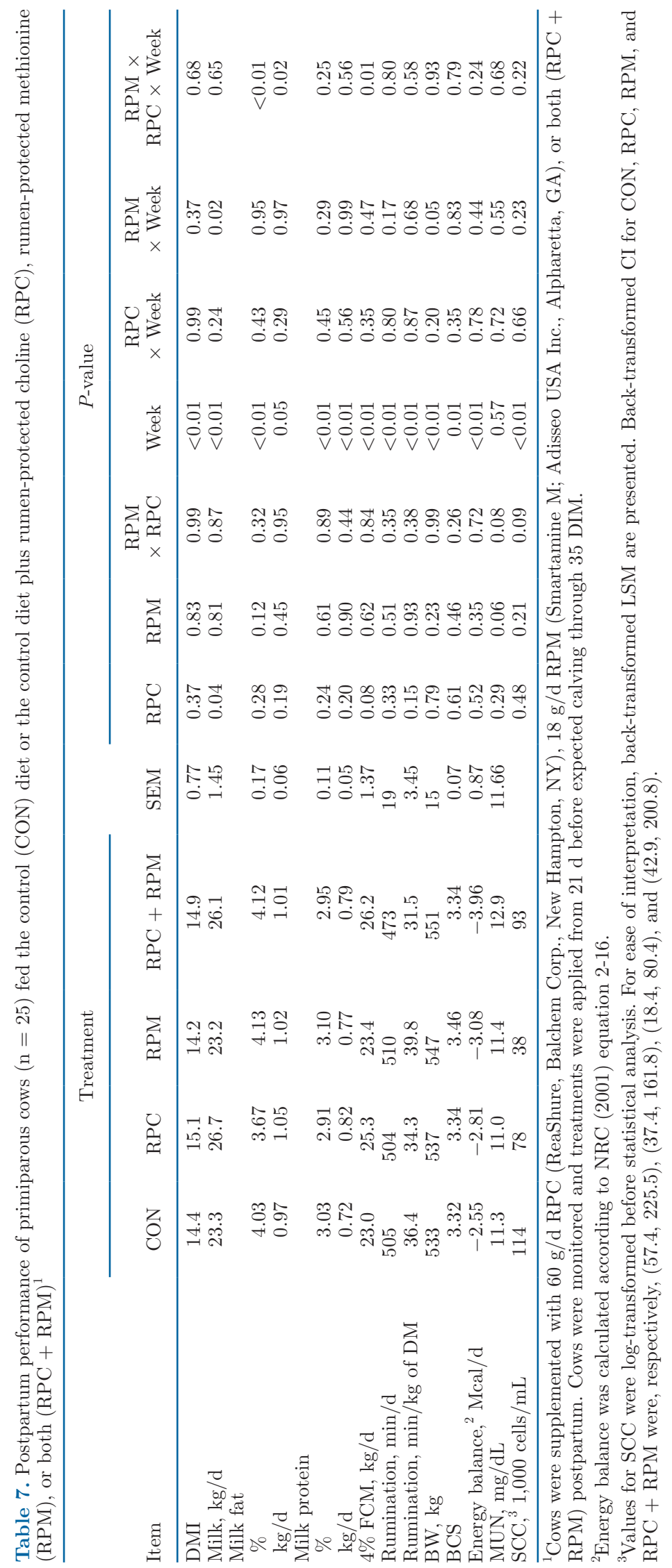


A

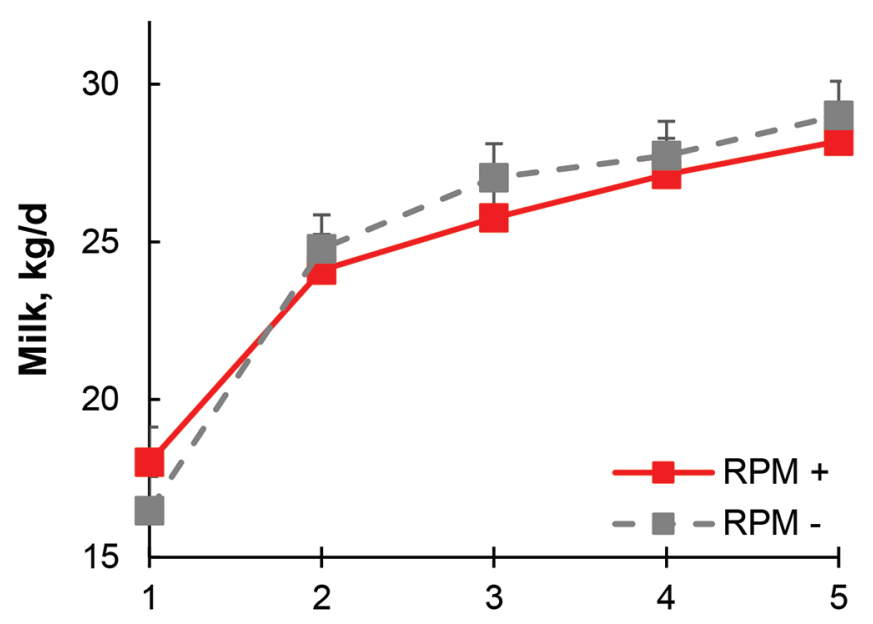

B

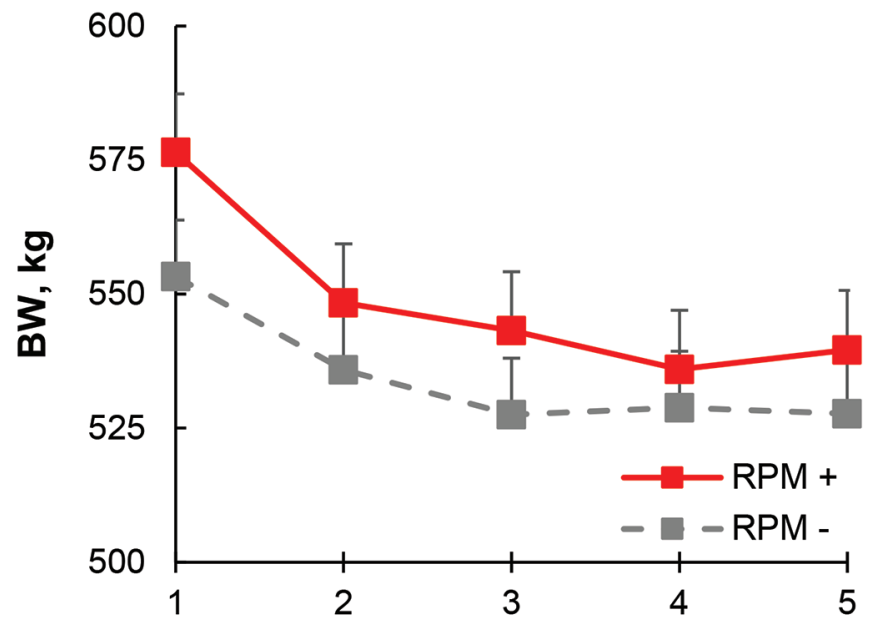

C

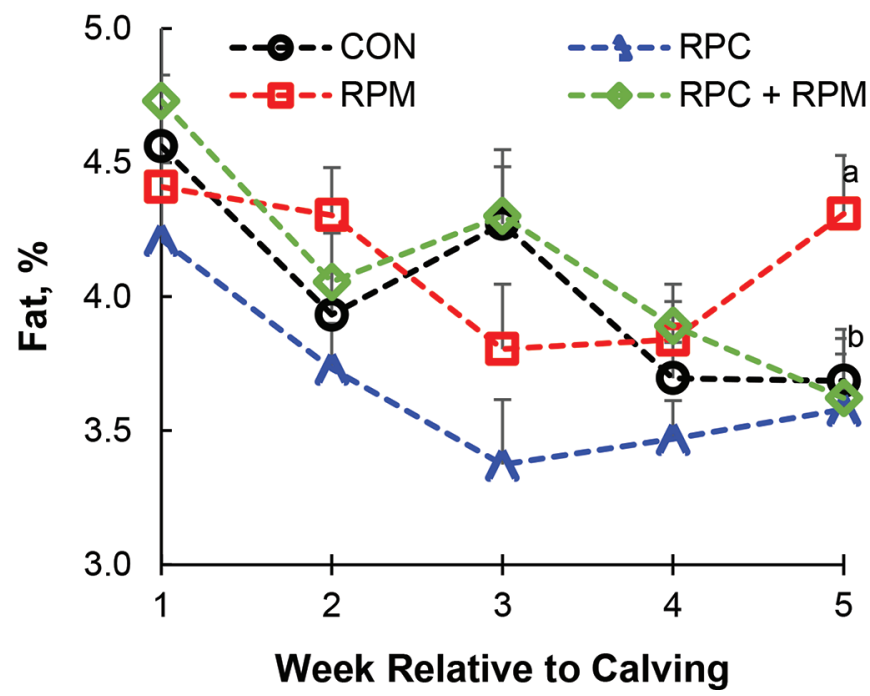

D

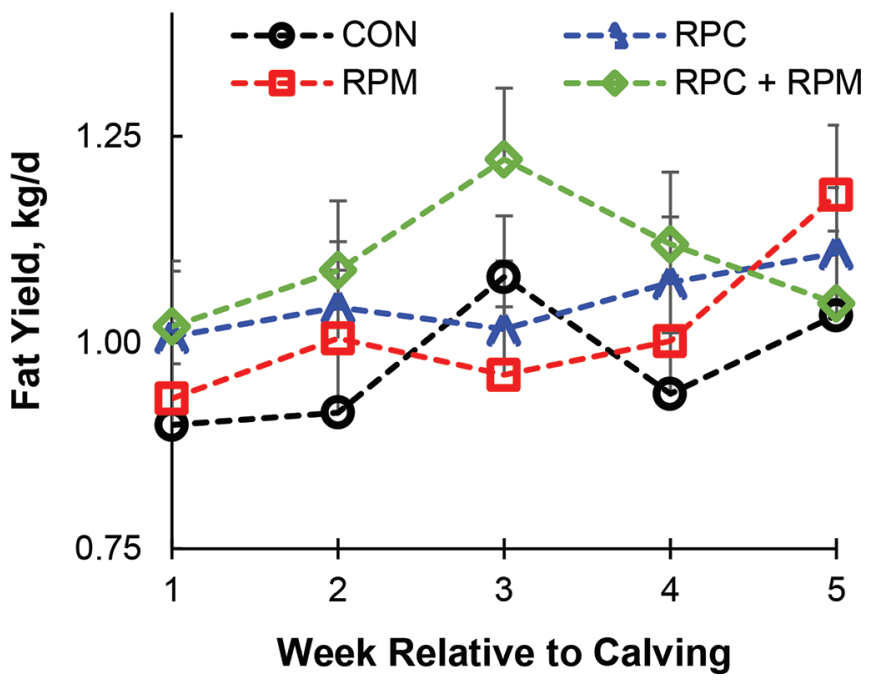

Figure 2. Milk yield (A), postpartum BW (B), milk fat percentage (C), and milk fat yield (D) for primiparous cows fed the control diet $(\mathrm{CON}), 60 \mathrm{~g} / \mathrm{d}$ rumen-protected choline (RPC) or $12 \mathrm{~g} / \mathrm{d}$ rumen-protected methionine (RPM) prepartum and $18 \mathrm{~g} / \mathrm{d} \mathrm{RPM}$ postpartum, or both $(\mathrm{RPC}+\mathrm{RPM})$, from $21 \mathrm{~d}$ before expected calving through 35 DIM. We found RPM $\times$ week interactions for milk yield $(P=0.02)$ and postpartum BW $(P=0.05)$ and an RPM $\times \mathrm{RPC} \times$ week interaction for milk fat percentage $(P<0.01)$ and fat yield $(P=0.02)$. Different letters $($ a, b) within a week indicate significantly different individual means $(P<0.05)$.

to lactation (Grummer, 2008). Thus, it may not necessarily be advantageous to increase milk fat production during this time, especially considering that a large portion of FA secreted in milk during early lactation is derived from preformed FA from body reserves (Kay et al., 2005). However, we did not observe any treatment effects on energy balance, suggesting that the positive effect of RPM on milk fat concentration (and yield) did not reflect a greater negative energy balance. Because the multiparous cows in the current study did not endure excessive negative energy balance postpartum (mean of $-3.2 \mathrm{Mcal} / \mathrm{d}$ ), this observation may not be the case in situations where cows are in a greater negative energy balance.

Primiparous Cows. Unlike multiparous cows, treatment effects on milk fat production for primiparous cows were more subtle. The $\mathrm{RPC} \times \mathrm{RPM}$ $\times$ week interaction $(P<0.01$; Figure $2 \mathrm{C})$ indicated that supplementation of RPM appeared to mitigate an $\mathrm{RPC}$-induced reduction in milk fat concentration at wk 


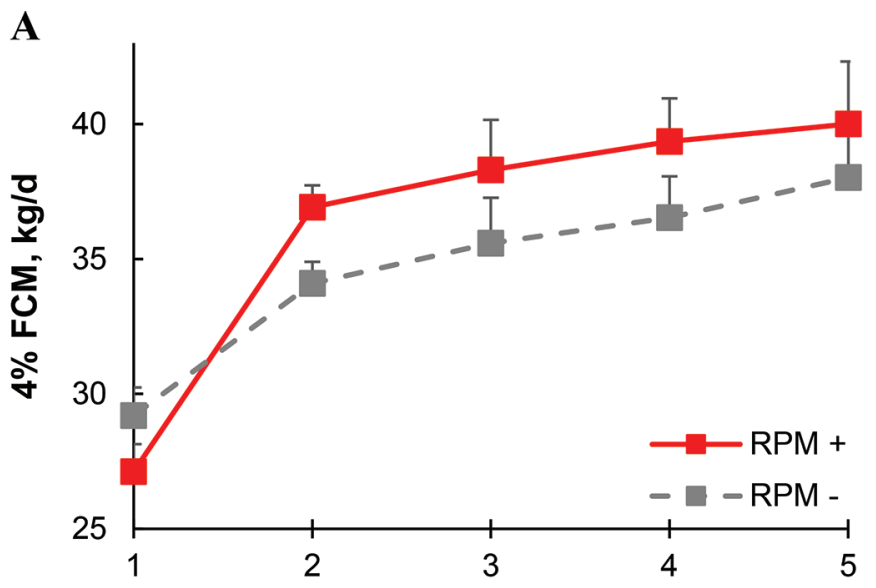

B

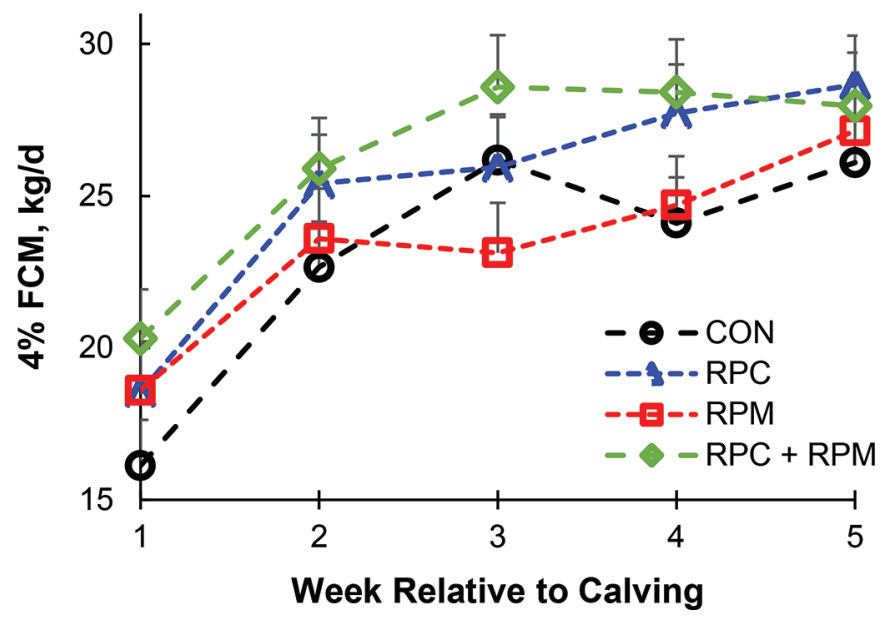

Figure 3. Fat-corrected milk for multiparous (A) and primiparous cows (B) fed the control diet (CON), $60 \mathrm{~g} / \mathrm{d}$ rumen-protected choline (RPC) or $12 \mathrm{~g} / \mathrm{d}$ rumen-protected methionine (RPM) prepartum and $18 \mathrm{~g} / \mathrm{d}$ RPM postpartum, or both (RPC + RPM), from $21 \mathrm{~d}$ before expected calving through 35 DIM. We found RPC $\times \mathrm{RPM} \times$ week interactions for multiparous cows $(P<0.01)$ and primiparous cows $(P=0.01)$

3 postpartum. Furthermore, RPM increased milk fat percentage in the absence of RPC during wk 5. These responses, in addition to those observed for multiparous cows, indicate a positive effect of RPM on milk fat concentration during the periparturient period. Milk fat yield responses were confined to wk 3 postpartum, where RPC increased fat yield only in the presence of $\mathrm{RPM}(\mathrm{RPC} \times \mathrm{RPM} \times$ week interaction: $P=0.02$; Figure 2D). Changes in FCM yield mirrored changes in milk fat yield (Figure $3 \mathrm{~B}$; RPC $\times \mathrm{RPM} \times$ week: $P$ $=0.01$ ), where RPC increased FCM in the presence of RPM during wk 3. Because these treatment effects were mostly isolated to wk 3 postpartum and did not occur at any other time during the study, these results should be interpreted with caution.

\section{Postpartum Performance: Milk Protein Production}

Multiparous Cows. Supplying supplemental Met during established lactation (Zanton et al., 2014) and during the periparturient period (Osorio et al., 2013; Zhou et al., 2016a; Batistel et al., 2017) generally increases milk protein yield and concentration. Lack of a consistent, characteristic increase in milk protein concentration in response to supplemental dietary Met (Zanton et al., 2014) suggests that Met supply was not substantially limiting for the multiparous cows in our study.

In absence of RPM, RPC decreased milk protein concentration but had no effect when fed in conjunction with RPM $(\mathrm{RPC} \times \mathrm{RPM}$ interaction: $P=0.01$; Table $6)$. This observation was likely the result of a dilution effect, because it coincided with an increase in milk volume for cows on this treatment (Table 6 ). Furthermore, a tendency for an RPM $\times \mathrm{RPC} \times$ week interaction $(P$ $=0.10 ;$ Figure $4 \mathrm{~A}$ ) indicated that this negative effect of RPC in absence of RPM was localized to wk 1 and 2 postpartum. This effect was further magnified during wk 1 postpartum, where RPM enhanced milk protein concentration in the presence of RPC (Figure 4A). Because choline and Met metabolism are integrated, one might expect that providing supplemental choline would spare Met to enhance protein production. However, our results, as well as the meta-analysis of several experiments by Arshad et al. (2020) that showed no change in milk protein concentration in response to supplemental choline, do not support this hypothesis. The fact that supplementing RPM offset the RPC-induced reduction in milk protein percentage for multiparous cows in our study, particularly during wk 1 and 2 (Figure 4A), suggests that RPC may have increased Met requirements during this time.

Milk urea nitrogen concentration is a useful tool for evaluating nitrogen efficiency and determining when dietary protein is in excess (Jonker et al., 1998; Godden et al., 2001). We observed a tendency for an RPM $\times \mathrm{RPC} \times$ week interaction $(P=0.10)$ whereby $\mathrm{RPM}$ reduced MUN in absence of RPC at wk 1 but increased it in the presence of RPC at wk 4. Furthermore, RPC reduced MUN in the absence of RPM at wk 2 (Figure 4B). Although Zhou et al. (2016a) did not observe effects of RPC or RPM on MUN during the periparturient period, our observations suggest that RPC and RPM may affect apparent nitrogen utilization during the periparturient period. However, more research is required to make additional inferences regarding this hypothesis. 
A

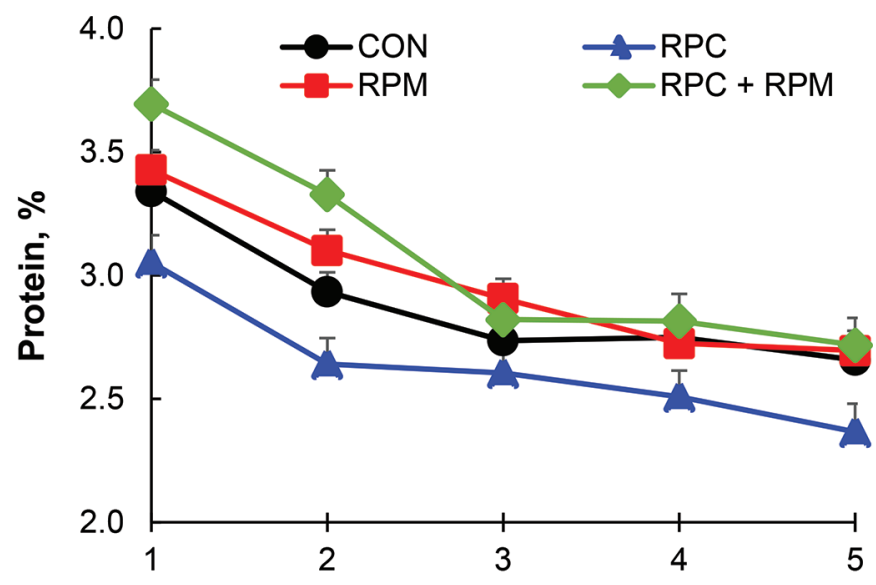

B

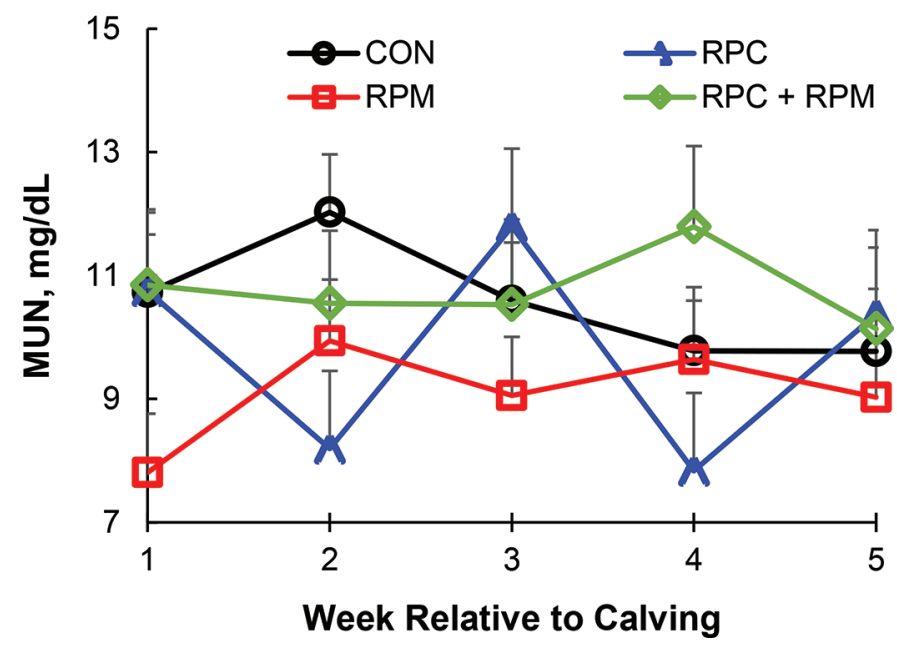

Figure 4. Milk protein percentage (A) and MUN (B) for multiparous cows fed the control diet $(\mathrm{CON}), 60 \mathrm{~g} / \mathrm{d}$ rumen-protected choline $(\mathrm{RPC})$ or $12 \mathrm{~g} / \mathrm{d}$ rumen-protected methionine $(\mathrm{RPM})$ prepartum and $18 \mathrm{~g} / \mathrm{d}$ RPM postpartum, or both (RPC + RPM), from $21 \mathrm{~d}$ before expected calving through 35 DIM. We found a tendency for an RPM $\times \mathrm{RPC} \times$ week interaction for milk protein percentage $(P=0.10)$ and $\operatorname{MUN}(P=0.08)$.

Primiparous Cows. Milk protein percentage and yield were not affected by treatment in primiparous cows (Table 7). The lack of an effect of RPM on protein yield or concentration suggests that Met was not limiting for primiparous cows. The diets for this study were formulated according to NRC (2001) recommendations for Met, which were based on requirements for mid-lactation multiparous cows. Although primiparous cows are still growing, their lower production relative to mid-lactation multiparous cows could translate to a lower Met requirement. If Met were not limiting for primiparous cows in this study, responses to RPM would have been diminished. This hypothesis may also explain the minimal milk fat responses to RPM for primiparous cows relative to multiparous cows in this study.

Although milk protein production was unaffected by treatment, a tendency $(P=0.08)$ for an $\mathrm{RPC} \times \mathrm{RPM}$ interaction indicated that RPM increased MUN in the presence of RPC. This finding is similar to our observation for multiparous cows at wk 4 postpartum, and suggests a reduction in nitrogen efficiency when RPM was fed with RPC.

\section{Postpartum Blood Metabolites}

Multiparous Cows. Postpartum plasma glucose and BHB were unaffected by treatment in multiparous cows, which is similar to results from previous studies (Zhou et al., 2016a; Zenobi et al., 2018a). However, we observed an RPC $\times$ week interaction $(P=0.03$; Table $5)$, which indicated that RPC reduced plasma FA during wk 4 postpartum (Figure 1B). Our observations are contrary to those of Zhou et al. (2016a) and Zenobi et al. (2018a), who showed no effect of RPC on plasma FA. However, in their recent meta-analysis, Arshad et al. (2020) reported a reduction in plasma FA in response to RPC. Our observations, in conjunction with those summarized by Arshad et al. (2020), suggest that RPC may have some ability to modify either body tissue mobilization or FA uptake by the mammary gland or liver during the periparturient period. However, further investigation regarding this hypothesis is needed, as we did not observe any effect of RPC on postpartum BCS.

Primiparous Cows. The RPC-induced increase in plasma $\mathrm{BHB}$ before calving carried through to the postpartum period, where RPC increased plasma $\mathrm{BHB}$ concentrations $(P=0.02$; Table 5$)$. This result conflicts with those observed for multiparous cows in the current study as well as those reported by others for multiparous cows (Zhou et al., 2016a; Zenobi et al., 2018a). Interestingly, plasma FA concentration was not affected by RPC, which would be expected if the elevation in plasma BHB concentration was related to the rate of body tissue mobilization.

\section{Liver Triglyceride}

Liver TG content was not affected by RPM in multior primiparous cows (Table 8), although liver TG levels were relatively low for all treatments, which may have minimized responses to RPC or RPM. Liver TG content below $1 \%$ on a wet basis is considered normal, whereas TG levels between 1 and $5 \%$ on a wet basis are classified as mild fatty liver (Bobe et al., 2004). If the DM content of liver tissue is assumed to be approximately 
Table 8. Pre- and postpartum liver triglyceride content (TG, \% DM) of primi- and multiparous cows ( $\mathrm{n}=23$ and 29 , respectively) fed the control diet $(\mathrm{CON})$ or the control diet plus rumen-protected choline $(\mathrm{RPC})$, rumen-protected methionine $(\mathrm{RPM})$, or both $(\mathrm{RPC}+\mathrm{RPM})^{1}$

\begin{tabular}{|c|c|c|c|c|c|c|c|c|}
\hline Liver $\mathrm{TG},{ }^{2} \% \mathrm{DM}$ & \multicolumn{4}{|c|}{ Treatment } & SEM & \multicolumn{3}{|c|}{$P$-value } \\
\hline \multicolumn{9}{|l|}{ Primiparous } \\
\hline Prepartum & 1.40 & 1.77 & 1.42 & 1.85 & 0.34 & 0.24 & 0.88 & 0.93 \\
\hline Postpartum & 1.89 & 2.33 & 2.54 & 2.41 & 0.43 & 0.72 & 0.41 & 0.52 \\
\hline Postpartum + Cov & 1.96 & 1.89 & 2.60 & 2.30 & 0.40 & 0.65 & 0.20 & 0.78 \\
\hline \multicolumn{9}{|l|}{ Multiparous } \\
\hline Postpartum + Cov & 5.83 & 4.05 & 5.11 & 4.73 & 0.94 & 0.26 & 0.98 & 0.48 \\
\hline
\end{tabular}

${ }^{1}$ Prepartum, cows were supplemented with $60 \mathrm{~g} / \mathrm{d}$ RPC (ReaShure, Balchem Corp., New Hampton, NY), $12 \mathrm{~g} / \mathrm{d}$ RPM (Smartamine M; Adisseo USA Inc., Alpharetta, GA), or both. Postpartum, cows were supplemented with $60 \mathrm{~g} / \mathrm{d}$ RPC, $18 \mathrm{~g} / \mathrm{d}$ RPM, or both. Cows were monitored and treatments were applied from $21 \mathrm{~d}$ before expected calving through 35 DIM.

${ }^{2}$ Prepartum liver samples were collected on the day of study enrollment (19 $\pm 2 \mathrm{~d}$ before calving). Postpartum liver samples were collected on $\mathrm{d}$ 7 postpartum. Postpartum + Cov values $=$ postpartum LSM that are covariate (Cov)-adjusted for prepartum liver TG values.

$30 \%$, the average postpartum liver TG content for the cows in our study was 1.5 and $0.7 \%$ for multiparous and primiparous cows, respectively. Thus, the cows in our study did not have a high degree of liver TG accumulation, so PC may not have been limiting TG export from the liver. The lack of effect of RPC or RPM on liver TG observed in the current study is similar to results presented elsewhere (Osorio et al., 2013; Zhou et al., 2016b; Batistel et al., 2017). Responses for the current study and others suggest that additional choline and Met were utilized to support milk and milk component production for both primi- and multiparous cows rather than PC synthesis for TG export.

Studies that used feed restriction to induce negative energy balance in dry cows have shown that RPC can reduce liver TG accumulation (Cooke et al., 2007; Zenobi et al., 2018b). Pinotti et al. (2002) hypothesized that choline increases the rate of TG export from the liver by increasing the availability of PC and subsequently increasing the production of very low density lipoprotein. This seems to be the case for dry cows under conditions of negative energy balance with energy deficits of approximately $9 \mathrm{Mcal} / \mathrm{d}$ (Cooke et al., 2007; Zenobi et al., 2018b). Results obtained from primi- and multiparous cows in this study and in a meta-analysis of multiparous cow experiments (Arshad et al., 2020) do support this concept. However, cows in our study did not experience severe negative energy balance, with a mean nadir of -6.6 and $-5.0 \mathrm{Mcal} / \mathrm{d}$ for multiparous and primiparous cows, respectively. Furthermore, cows in our study likely did not experience excessive body reserve mobilization, as BW decreased only approximately $30 \mathrm{~kg}$ between calving and wk 5 postpartum. Thus, it is possible that the rate of body tissue mobilization for the cows in our study was not great enough to necessitate additional choline to support TG export.

\section{Variation in Production Responses to RPC and RPM}

Variation in responses to RPM and RPC supplementation during the periparturient period are likely due to many factors, including the Met and choline requirements of the cow, the amount of metabolizable Met supplied in the diet and in relation to other amino acids, the amount and type of protein supplied during the pre- or postpartum period, and the prepartum metabolic state and adiposity of the cow. Zahra et al. (2006) showed that RPC had a positive milk yield response in overconditioned periparturient cows $(\mathrm{BCS} \geq 4)$. However, differences in adiposity likely had minimal influence over treatment effects in the current study, because only 5 animals had an initial BCS $\geq 4$.

\section{Primiparous Versus Multiparous Cows}

The results of the current study indicate that feeding $\mathrm{RPC}$ and RPM during the periparturient period can have positive but different magnitudes and types of effects on the production of primiparous and multiparous cows. Feeding RPM had an overall positive effect on milk fat concentration and tended to have an overall positive effect on milk fat yield for multiparous cows. In contrast, RPM had minor effects on milk fat concentration and yield for primiparous cows. In multiparous cows, feeding RPC increased milk yield only when fed in the absence of RPM, whereas RPC increased milk yield in primiparous cows regardless of RPM supplementation.

The differences in responses by parity can likely be attributed to a difference in choline and Met requirements for these 2 groups of cows. Although this experiment was not specifically designed to investigate treatment $\times$ parity interactions, the differences in responses to 
treatment suggest differential nutrient needs for these groups of cows. The lack of a uniform response among primi- and multiparous cows is not necessarily surprising, as parity has a large effect on postpartum production. In this study, multiparous cows produced $11 \mathrm{~kg} / \mathrm{d}$ of FCM more than primiparous cows, on average (36 $\mathrm{kg} / \mathrm{d}$ vs. $25 \mathrm{~kg} / \mathrm{d}$ ), and these differences in production likely contribute to different apparent choline and Met requirements. The average productive life of dairy cows in the United States is 26.7 mo (Dechow and Hansen, 2017), or approximately 2.7 lactations, so primiparous cows make up a significant portion of the US dairy herd. Therefore, future experiments should be designed to further investigate these putative differences in parity with respect to Met and choline requirements so that strategies can be implemented to better meet the individual needs of primi- versus multiparous cows.

\section{CONCLUSIONS}

Our study lends support to the hypothesis that primi- and multiparous cows have different requirements for choline and Met. Providing supplemental Met as RPM during the periparturient period had overall positive effects on milk fat concentration for multiparous cows. Feeding choline as RPC to multiparous cows increased milk yield only in the absence of RPM, whereas RPC had positive effects on milk yield for primiparous cows irrespective of RPM supplementation. The lack of an effect of RPM on milk protein concentration for primiparous cows suggests that current NRC (2001) recommendations for dietary Met may be too high for periparturient primiparous cows. However, because cows in our study did not experience severe negative energy balance (mean nadirs of -6.6 and $-5.0 \mathrm{Mcal} / \mathrm{d}$ for multiparous and primiparous cows, respectively), responses to RPC and RPM may have been muted for both groups of cows. Further investigation into potential interactions between parity and choline or Met supplementation to periparturient cows is warranted.

\section{ACKNOWLEDGMENTS}

The authors acknowledge the staff of the Central Maryland Research and Education Center Dairy Unit (Ellicott City, MD) for their assistance with animal care and management. The authors are also grateful to Claudia Gomez and Emily Davis (University of Maryland, Department of Animal and Avian Sciences, College Park, MD) for providing assistance with sample and data collection. Funding for this study was provided by Balchem Corporation (New Hampton, NY). The authors have not stated any conflicts of interest.

\section{REFERENCES}

Arshad, U., M. G. Zenobi, C. R. Staples, and J. E. P. Santos. 2020. Meta-analysis of the effects of supplemental rumen-protected choline during the transition period on performance and health of dairy cows. J. Dairy Sci. 103:282-300.

Barkema, H. W., M. A. G. von Keyserlingk, J. P. Kastelic, T. J. G. M. Lam, C. Luby, J.-P. Roy, S. J. LeBlanc, G. P. Keefe, and D. F. Kelton. 2015. Invited review: Changes in the dairy industry affecting dairy cattle health and welfare. J. Dairy Sci. 98:7426-7445. https://doi.org/10.3168/jds.2015-9377.

Batistel, F., J. M. Arroyo, A. Bellingeri, L. Wang, B. Saremi, C. Parys, E. Trevisi, F. C. Cardoso, and J. J. Loor. 2017. Ethyl-cellulose rumen-protected methionine enhances performance during the periparturient period and early lactation in Holstein dairy cows. J. Dairy Sci. 100:7455-7467. https://doi.org/10.3168/jds.2017-12689.

Bauman, D. E., K. J. Harvatine, and A. L. Lock. 2011. Nutrigenomics, rumen-derived bioactive fatty acids, and the regulation of milk fat synthesis. Annu. Rev. Nutr. 31:299-319. https://doi.org/10.1146/ annurev.nutr.012809.104648.

Bobe, G., J. W. Young, and D. C. Beitz. 2004. Invited review: Pathology, etiology, prevention, and treatment of fatty liver in dairy cows. J. Dairy Sci. 87:3105-3124. https://doi.org/10.3168/jds .S0022-0302(04)73446-3.

Cooke, R. F., N. Silva Del Río, D. Z. Caraviello, S. J. Bertics, M. H. Ramos, and R. R. Grummer. 2007. Supplemental choline for prevention and alleviation of fatty liver in dairy cattle. J. Dairy Sci. 90:2413-2418. https://doi.org/10.3168/jds.2006-028.

Dechow, C. D., and L. B. Hansen. 2017. Capitalizing on breed differences and heterosis. Pages 369-378 in Large Dairy Herd Management. 3rd ed. D. K. Beede, ed. American Dairy Science Association, Champaign, IL.

Djemali, M., P. J. Berger, and A. E. Freeman. 1987. Ordered categorical sire evaluation for dystocia in Holsteins. J. Dairy Sci. 70:23742384. https://doi.org/10.3168/jds.S0022-0302(87)80298-9.

Elek, P., J. R. Newbold, T. Gaal, L. Wagner, and F. Husveth. 2008. Effects of rumen-protected choline supplementation on milk production and choline supply of periparturient dairy cows. Animal 2:1595-1601. https://doi.org/10.1017/S1751731108002917.

Folch, J., M. Lees, and G. Sloane Stanley. 1957. A simple method for the isolation and purification of total lipids from animal tissues. J. Biol. Chem. 226:497-509.

Foster, L. B., and R. T. Dunn. 1973. Stable reagents for determination of serum triglycerides by a colorimetric Hantzsch condensation method. Clin. Chem. 19:338-340. https://doi.org/10.1093/ clinchem/19.3.338.

Godden, S. M., K. D. Lissemore, D. F. Kelton, K. E. Leslie, J. S. Walton, and J. H. Lumsden. 2001. Factors associated with milk urea concentrations in Ontario dairy cows. J. Dairy Sci. 84:107-114. https://doi.org/10.3168/jds.S0022-0302(01)74458-X.

Grummer, R. R. 2008. Nutritional and management strategies for the prevention of fatty liver in dairy cattle. Vet. J. 176:10-20. https:/ /doi.org/10.1016/j.tvjl.2007.12.033.

Jonker, J. S., R. A. Kohn, and R. A. Erdman. 1998. Using milk urea nitrogen to predict nitrogen excretion and utilization efficiency in lactating dairy cows. J. Dairy Sci. 81:2681-2692. https://doi.org/ 10.3168/jds.S0022-0302(98)75825-4.

Jorritsma, R., H. Jorritsma, Y. H. Schukken, P. C. Bartlett, T. Wensing, and G. H. Wentink. 2001. Prevalence and indicators of post partum fatty infiltration of the liver in nine commercial dairy herds in The Netherlands. Livest. Prod. Sci. 68:53-60. https://doi .org/10.1016/S0301-6226(00)00208-6.

Kaufman, E. I., S. J. LeBlanc, B. W. McBride, T. F. Duffield, and T. J. DeVries. 2016. Association of rumination time with subclinical ketosis in transition dairy cows. J. Dairy Sci. 99:5604-5618. https: //doi.org/10.3168/jds.2015-10509.

Kay, J. K., W. J. Weber, C. E. Moore, D. E. Bauman, H. ChesterJones, L. B. Hansen, B. A. Crooker, and L. H. Baumgard. 2005. Effects of week of lactation and genetic selection for milk yield on milk fatty acid composition in Holstein cows. J. Dairy Sci 
88:3886-3893. https://doi.org/10.3168/jds.S0022-0302(05)73074 $-5$.

Leiva, T., R. F. Cooke, A. P. Brandão, R. S. Marques, and J. L. M. Vasconcelos. 2015. Effects of rumen-protected choline supplementation on metabolic and performance responses of transition dairy cows. J. Anim. Sci. 93:1896-1904. https://doi.org/10.2527/ jas.2014-8606.

Li, P., C. Zhou, X. Li, M. Yu, M. Li, and X. Gao. 2019. CRTC2 is a key mediator of amino acid-induced milk fat synthesis in mammary epithelial cells. J. Agric. Food Chem. 67:10513-10520. https: //doi.org/10.1021/acs.jafc.9b04648.

Li, Z., and D. E. Vance. 2008. Thematic review series: Glycerolipids. Phosphatidylcholine and choline homeostasis. J. Lipid Res. 49:1187-1194. https://doi.org/10.1194/jlr.R700019-JLR200.

Meister, A., and M. E. Anderson. 1983. Glutathione. Annu. Rev. Biochem. 52:711-760. https://doi.org/10.1146/annurev.bi.52.070183 .003431 .

National Research Council. 2001. Nutrient Requirements of Dairy Cattle. 7th rev. ed. Natl. Acad. Press, Washington, DC.

Ordway, R. S., S. E. Boucher, N. L. Whitehouse, C. G. Schwab, and B. K. Sloan. 2009. Effects of providing two forms of supplemental methionine to periparturient Holstein dairy cows on feed intake and lactational performance. J. Dairy Sci. 92:5154-5166. https:// doi.org/10.3168/jds.2009-2259.

Osorio, J. S., P. Ji, J. K. Drackley, D. Luchini, and J. J. Loor. 2013. Supplemental Smartamine M or MetaSmart during the transition period benefits postpartal cow performance and blood neutrophil function. J. Dairy Sci. 96:6248-6263. https://doi.org/10.3168/jds $2012-5790$

Piepenbrink, M. S., and T. R. Overton. 2003. Liver metabolism and production of cows fed increasing amounts of rumen-protected choline during the periparturient period. J. Dairy Sci. 86:17221733. https://doi.org/10.3168/jds.S0022-0302(03)73758-8.

Pinotti, L., A. Baldi, and V. Dell'Orto. 2002. Comparative mammalian choline metabolism with emphasis on the high-yielding dairy cow. Nutr. Res. Rev. 15:315-332. https://doi.org/10.1079/NRR200247.

Qi, H., C. Meng, X. Jin, X. Li, P. Li, and X. Gao. 2018. Methionine promotes milk protein and fat synthesis and cell proliferation via the SNAT2-PI3K signaling pathway in bovine mammary epithelial cells. J. Agric. Food Chem. 66:11027-11033. https://doi.org/ 10.1021/acs.jafc.8b04241.

Wildman, E. E., G. M. Jones, P. E. Wagner, R. L. Boman, H. F. Troutt Jr., and T. N. Lesch. 1982. A dairy cow body condition scoring system and its relationship to selected production characteristics. J. Dairy Sci. 65:495-501. https://doi.org/10.3168/jds .S0022-0302(82)82223-6.

Yuan, L., and N. Kaplowitz. 2009. Glutathione in liver diseases and hepatotoxicity. Mol. Aspects Med. 30:29-41. https://doi.org/10 $.1016 /$ j.mam.2008.08.003.

Zahra, L. C., T. F. Duffield, K. E. Leslie, T. R. Overton, D. Putnam, and S. J. LeBlanc. 2006. Effects of rumen-protected choline and monensin on milk production and metabolism of periparturient dairy cows. J. Dairy Sci. 89:4808-4818. https://doi.org/10.3168/ jds.S0022-0302(06)72530-9.

Zanton, G. I., G. R. Bowman, M. Vázquez-Añón, and L. M. Rode. 2014. Meta-analysis of lactation performance in dairy cows receiving supplemental dietary methionine sources or postruminal infusion of methionine. J. Dairy Sci. 97:7085-7101. https://doi.org/10 .3168/jds.2014-8220.

Zeisel, S. H. 1981. Dietary choline: Biochemistry, physiology, and pharmacology. Annu. Rev. Nutr. 1:95-121. https://doi.org/10.1146/ annurev.nu.01.070181.000523.

Zeisel, S. H., and K. da Costa. 2009. Choline: An essential nutrient for public health. Nutr. Rev. 67:615-623. https://doi.org/10.1111/ j.1753-4887.2009.00246.x.

Zenobi, M. G., R. Gardinal, J. E. Zuniga, A. L. G. Dias, C. D. Nelson, J. P. Driver, B. A. Barton, J. E. P. Santos, and C. R. Staples. 2018a. Effects of supplementation with ruminally protected choline on performance of multiparous Holstein cows did not depend upon prepartum caloric intake. J. Dairy Sci. 101:1088-1110. https: //doi.org/10.3168/jds.2017-13327.

Zenobi, M. G., T. L. Scheffler, J. E. Zuniga, M. B. Poindexter, S. R. Campagna, H. F. Castro Gonzalez, A. T. Farmer, B. A. Barton, J. E. P. Santos, and C. R. Staples. 2018b. Feeding increasing amounts of ruminally protected choline decreased fatty liver in nonlactating, pregnant Holstein cows in negative energy status. J. Dairy Sci. 101:5902-5923. https://doi.org/10.3168/jds.2017-13973.

Zhou, Z., O. Bulgari, M. Vailati-Riboni, E. Trevisi, M. A. Ballou, F. C. Cardoso, D. N. Luchini, and J. J. Loor. 2016b. Rumen-protected methionine compared with rumen-protected choline improves immunometabolic status in dairy cows during the peripartal period. J. Dairy Sci. 99:8956-8969. https://doi.org/10.3168/jds.2016 -10986 .

Zhou, Z., M. Vailati-Riboni, E. Trevisi, J. K. Drackley, D. N. Luchini, and J. J. Loor. 2016a. Better postpartal performance in dairy cows supplemented with rumen- protected methionine compared with choline during the peripartal period. J. Dairy Sci. 99:8716-8732. https://doi.org/10.3168/jds.2015-10525.

Zom, R. L. G., J. van Baal, R. M. A. Goselink, J. A. Bakker, M. J. de Veth, and A. M. van Vuuren. 2011. Effect of rumen-protected choline on performance, blood metabolites, and hepatic triacylglycerols of periparturient dairy cattle. J. Dairy Sci. 94:4016-4027. https://doi.org/10.3168/jds.2011-4233.

\section{ORCIDS}

S. B. Potts $\odot$ https://orcid.org/0000-0002-4952-4193

C. M. Scholte $\odot$ https://orcid.org/0000-0002-6524-1249

K. M. Moyes (ํ) https://orcid.org/0000-0003-3591-3849

R. A. Erdman (®) https://orcid.org/0000-0001-6954-4282 